\title{
The Practice of Custom in India's Recognition of Forest Right's Act: Case Studies from Kalahandi, Odisha
}

Matthew B. Shutzer

\section{(2) OpenEdition}

\section{Journals}

Electronic version

URL: http://journals.openedition.org/samaj/3623

DOI: $10.4000 /$ samaj.3623

ISSN: 1960-6060

Publisher

Association pour la recherche sur l'Asie du Sud (ARAS)

\section{Electronic reference}

Matthew B. Shutzer, «The Practice of Custom in India's Recognition of Forest Right's Act: Case Studies from Kalahandi, Odisha », South Asia Multidisciplinary Academic Journal [Online], 7| 2013, Online since 15 October 2013, connection on 30 April 2019. URL : http://journals.openedition.org/ samaj/3623 ; DOI : 10.4000/samaj.3623

This text was automatically generated on 30 April 2019.

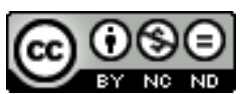

This work is licensed under a Creative Commons Attribution-NonCommercial-NoDerivatives 4.0 International License. 


\title{
The Practice of Custom in India's Recognition of Forest Right's Act: Case Studies from Kalahandi, Odisha
}

\author{
Matthew B. Shutzer
}

\section{Introduction}

1 This article investigates the category 'custom' as it is defined in the Scheduled Tribes and Other Traditional Forest Dwellers Act, 2006, also known as the Indian Forest Rights Act (hereafter FRA) and the manner in which this particular concept of custom is used as a mode of developmental argumentation in Kalahandi, Odisha. By custom the FRA refers to a legal notification of customary entitlements to forest land claimed by members of Scheduled Tribe (ST), Scheduled Caste and Other Backward Caste (OBC) communities, though ST petitioners predominate as the FRA's practical beneficiaries. ${ }^{1}$ Custom is here understood as proprietary and usufruct rights previously unrecognized by the Government of India. This retroactive recognition of rights assigns forest land and forest resources on the basis of a claim to a particular political community, thereby redefining forest land that had been previously governed under regional variants of administrative stewardship. As the preamble to the FRA explains:

The forest rights on their (Scheduled Tribe and Other Traditional Forest Dweller) ancestral lands and habitats were not adequately recorded in the consolidation of state forests in the colonial as well as in independent India resulting in historical injustices to the forest dwelling scheduled tribes and other forest dwellers who are integral to the very sustainability and survival of the forest ecosystem. ${ }^{2}$

2 The sense of 'custom' described here denotes a political economic category strongly associated with both historical recognition and redistributive justice. Yet significantly, the final line in the above passage refers to a specific contemporary concern, the state of the environment, largely absent from previous movements to provide proprietary security to peasant households. The forest, as an agroecological space of diverse 
livelihood practices, ${ }^{3}$ represents an important comparative divergence from "land to the tiller' movements which earlier engaged with problems of landlordism and the rents of settled agriculture. ${ }^{4}$ Instead of solely articulating concerns over the social relations embedded within the distribution of agricultural rents, as 'land to the tiller' movements did for settled agricultural spaces, the FRA describes a form of both economic and social reproduction that is contingent upon the reproduction of the 'forest ecosystem', which the framers of the FRA assert in fact depends on the use of the forest by forest dwelling communities. The significance here lies in the legal articulation of a co-constructed sense of ecological spaces (Agrawal \& Sivaramakrishnan 2000, Latour 1993), pushing back against conservationist claims of forest resources as necessarily external to social interaction and therefore in need of reservation by the state. Yet as a caveat to this human centered vision of forest ecology, and as the primary site of conflict in the interpretation of the FRA which I wish to describe in this essay, customary entitlements to the forest and the environmental responsibilities that these entitlements imply are not construed merely in terms of the recognition of a previously unrecognized version of these properties and practices, but reify and reassemble a conception of customary indigenous practices ${ }^{5}$ that define the criteria for how indigenous communities are intended to act upon their environment. The conceptual problem I will repeatedly return to in the following pages is how the normative use of community, embedded within the language of the FRA, seeks to represent forest dwelling communities as environmental stewards dependent, in largely equal measure across households, on the land. ${ }^{6}$

3 Leaving the redistributive claims of the FRA for the time being, I would like to briefly consider what the constitution of indigenous custom, and therefore a particular reading of indigenous identity, entails. In Partha Chatterjee's dichotomous formulation of populations and citizens, the heterogeneous spaces and identities of 'populations' are codified through developmental strategies that permit members of these groups recourse to individual rights premised on collective identification. Heterogeneity here gains a semblance of political-legal legibility (Sivaramakrishnan 2012) anchored in a set of social relations between fixed communities. By applying Chatterjee's concept of 'populations,' I understand the project of custom under the FRA as a codification of indigenous communities in relation to an abstract space of forest resources, to other communities living within these spaces that are defined as non-indigenous, and to legal reservations that provide the basis for developmental claims made to the state (Ahuja 2009). The 'indigenous slot' (Karlsson 2003), which can be read alongside Chatterjee as utilizing custom to enumerate indigenous actors as a condition for resource entitlement to indigenous groups, maintains its salience beyond local or regional politics. Claims to indigeneity of course today are also interpenetrated by a set of global understandings forwarded by activists, non-governmental organizations and states for constituting the historical parameters of indigeneity in parts of Asia, Africa and Latin America (Hale 2002). Though the category of indigeneity has a complex history particular to India, ${ }^{7}$ there are multiple discursive convergences between regional instantiations mobilized by activists and developmental strategists concerned with the protection of these groups. The FRA is a site of discursive confluence for both the national and global trajectories by which indigeneity is represented in the present. ${ }^{8}$ In a general sense, these forms of discourse submit histories of agricultural subsistence, foraging and non-industrial livelihood practices, land alienation, and ecologically 'low-impact' consumption as signs of how indigenous groups labor in the forest. While I do not mean to diminish the specific 
historical processes that have established comparatives between distinct indigenous groups throughout India and the world, my work intends to highlight what this identity comes to signify in a particular social context. The case studies that I submit from Kalahandi, I argue, begin to suggest how political horizons formed through the legal practices of the FRA might be studied more locally, and the manner in which a concept such as 'indigenous custom' forms a type of political articulation for indigenous groups, their advocates and government officials that both constructs and redeploys enumerative categories in dynamic ways. Here, my method is to not presume a primary relationship between communities and the state, or communities and civil society activists; but to understand how the law intervenes within the intersections of political economy and political representation and what this might tell us about the forces that construct communities within developmental practices.

\section{The Spatial Distribution of Indigenous Claims}

In Lanjigarh, the district of Kalahandi where I conducted my fieldwork from 2008 to 2012, Khondadivasis represent $55 \%$ of the population, and members of various Scheduled Caste communities represent $25 \%$. Within these two groups, there are significant differences in landholding and livelihoods dependent upon factors such as cultivable land areas, access to wage labor opportunities, household size, relationships to panchayat members, and the type of forest administration in a given village. Long standing relationships to regional non-governmental organizations and the Orissa Tribal Empowerment and Livelihoods Programme (OTELP) also assists in this differentiation across and within villages. Between communities, Khonds typically practice a form of shifting cultivation in the forested hills that run through the district, while Scheduled Caste groups tend to cultivate in medium and lower-lying areas, and have historically engaged in commercial activities like distilling. These distinctions, both ecological and social, shed light on the 'community' based logic used for mapping forest spaces, a practice I attempt to assess in this section.

Under the FRA, both individuals and villages are allowed to claim tracts of forest land for either homestead (meaning deeds to houses on land formerly administered by the Forest or Revenue Department) or cultivable plots if they are able to prove three generations or seventy-five year sustained occupancy. Evidence that can be used to substantiate these claims include voting records, ration cards, oral histories, and any tangible improvements to the land in question, such as permanent residential structures or irrigation catchments. In addition to the oral interviews that comprise my ethnographic evidence, for this study I have reviewed FRA applications, lists of approved pattas (land deeds) returned to villages, and patta lists kept by district government offices. These documents demonstrate that approximately 50\% of FRA applications were approved for settlement in Lanjigarh, though not all of those approved ever received official settlement records or had their settlements duly recorded by local officials. At the time of my research in 2012, and as testimonies below will demonstrate, the three largest non-governmental organizations working in Lanjigarh to register FRA pattas had assisted only Khond communities to file applications, even though members of SC communities would have been eligible to do so. This was largely justified by a sense among NGO field workers that the district government, and in particular representatives from the Forest Department who help review FRA applications, would not approve requests from SC communities as they were viewed to have a lesser customary claim to forest resources than Khond 
applicants, and would also be less likely to observe conservation strictures given their presumed historical inclination towards commercial rather than agricultural livelihoods. ${ }^{9}$

The social distribution of eligibility also has a spatial referent within groups that identify themselves as Khonds. One of my first experiences working in Lanjigarh highlighted how distinctions between Khond households could not only be read as differential access to resources, but, in light of the implementation of the FRA, differential access to an 'authoritative'indigenous claim. These differences were particularly visible when unexpected ecological problems, such as monsoon flooding, exposed how nominally similar agroecological areas were comprised of multiple and often overlapping productive interests. In the village of Taliguda in September of 2008, for instance, an infrastructure project inaugurated under the Pradhan Mantri Gram Sadak Yojana (PMGSY) to build an approach road had been halted due to heavy monsoon flooding. Even by October, construction had not picked up again and villagers in Taliguda were unsure when contractors would return from the district capital to hire laborers for the work. During early September, flooding from the hills that ring the village had washed away crops and paddy bunds from medium and low-lying fields, a threat that is often averted through a system of small check-dams and diligent bund repairing labored over in the winter and early summer months. This season the flooding had been particularly strong. Surveying the damage, Jubrash Majhi, a Khond elder in Taliguda whose family farms ten acres of irrigated lowland paddy, explained to me that the increased frequency of the flooding was due to the irresponsible felling of sal trees by villagers in the upland hamlet of Carnomunda. Even though he had family in Carnomunda, Jubrash told, the community there was not thinking of how their actions affected the village in the valley below them. Taliguda Khonds had access to forest land for shifting cultivation too, though the hills in which they practiced dongar, the local name for the swidden plantation of small pulses and millets, were at a greater distance from the village and were more closely monitored by the Forest Department. Carnomunda, on the other hand, was not connected by road to the block and the hills that they cleared for dongar were codified as Village Forest, giving the village greater say over how to utilize the land.

7 Like Taliguda, Carnomunda is an all Khond village without a Scheduled Caste or Other Backward Caste minority. Taliguda is a much larger village, comprising over forty households, while Carnomunda has only 18. Taliguda also has large swathes of flat land long used for paddy cultivation, and it receives the bulk of the runoff from the hills, making even land of a medium elevation fertile for multiple harvest cycles. Carnomunda, on the other hand, is the archetypal image of the forested adivasi village. Narrow muddy trails through thick jungle convey day laborers, traders, and sometimes school children to and from the village. The only livestock raised here are goats and chickens, as villagers have no use for bullocks to plough their steep and stony dongar plots. Only six households cultivate small plots of paddy in upland areas that are relatively flat, while the majority of households primarily rely on three to four acres of dongar. At the time of my research in the village in 2008, the hills that press against Carnomunda's boundary were stripped bare of shrub and tree growth on the south side and yet were green and cultivated on the eastern. The southern areas look down on Taliguda. Carnomunda villagers told me that in three or four years the barren slopes would be green again. It was unfair therefore, I was told in a village meeting regarding the settlement of FRA pattas, for Taliguda villagers to complain of deforestation when their village benefitted not only from irrigation but from government subsidies for paddy. Carnomunda, they told me, received none of these 
benefits, not only because of the topography of the land surrounding the village but because the government had no schemes for improving or assisting dongar cultivation. Indeed, the Forest Department did everything they could to suggest to the villagers that their practices were illegal, even if they fell under the nominal sanctuary of the Village Forest designation..$^{10}$ If water run-off increased due to intensified shifting cultivation on the southern slopes of the hills, this was merely a consequence of Taliguda's geographical position relative to its smaller and more economically insecure upland neighbor.

In a similar meeting I observed in Taliguda, however, villagers there told a different story. Gungura Majhi, another relatively large landholder from Taliguda, explained to the NGO employee facilitating FRA claims there that Carnomunda was technically a settlement of Taliguda and therefore meetings regarding forest settlement should, in his view, be conducted with both villages considered as one. Since the watershed was linked by irrigation channels and because many Carnomunda villagers depended on seasonal wage work in Taliguda's rice fields, it only made sense to look at the watershed as a single area of mutually agreed upon tenurial claims. Villagers in Carnomunda resisted these overtures, however, arguing that if forest recognition was coming to the watershed it was important for Carnomunda villagers to secure the ten acres guaranteed to individual claimants under the FRA, rather than to openly compete with Taliguda for prized dongar land that could be claimed just as easily by outsiders with similarly vague appeals to customary occupancy. One villager in Carnomunda raised the point that since areas of the village dongar remain uncultivated during the fallow cycle, what would stop a villager in Taliguda from claiming a plot of that land as his or her own? Surely there were no marks upon the soil that would denote the low-growth shrub and sal as necessarily the property of a Carnomunda claimant.

9 This particularly acrimonious dispute was made all the worse by the conservation minded NGO facilitator siding with Taliguda, resulting in a delay of the patta applications for the entire watershed and an ultimate rejection of all dongar land, for which both villages had applied, by the District Level Committee (DLC) convened to review FRA applications. Yet this event points us towards a broader history of mapping claims in Kalahandi and the relationship between development and territorial demarcation. Although further work on this subject is needed to grasp how earlier developmental schemes under the Indian Forest Department have altered patterns of resource use by developing unique tenurial arrangements, a few general examples can demonstrate how Lanjigarh's local history of unmapped forest land fits into a larger regional history of Kalahandi.

Kalahandi has long been subject to varying representations as a marginal agricultural space. Its boundaries have been re-mapped three times since 1947. New districts have been carved out of 'greater Kalahandi' in order to reflect long-standing revenue arrangements based on older zamindari structures and to re-channel development funding into regional based projects with targeted demographics (NABCONS Orissa Regional Office, 2007: 8-14). More generally, the map of western Odisha was significantly redrawn in the territorial disputes of the 1930s and 1940s between estate holders and tributary princes to reflect new demands for mineral resources and timber in the late colonial economy (Prasad 2009). An early $20^{\text {th }}$ century British geologist surveying Kalahandi's soil types wrote an op-ed piece in the Times of India deriding the district's lack of infrastructure and condemning it to an 'obscurity' from which only geological prospecting could save it (1903). As late as the 1990s, Indian journalists used the term 
'Kalahandi Syndrome' to describe the regressive incomes and periodic food shortages that continued within the district despite significant developmental intervention. ${ }^{11}$

11 As a former princely state, Kalahandi's Maharaja, in the district capital of Bhawanipatna, administered over five major zamindaris, or revenue estates. Over the course of the $19^{\text {th }}$ century many of the tenures under the estate holders were reorganized to reflect patterns of arable land holding in the deltaic regions of Odisha and southern Bengal (Pati 1999a). Many Khonds, who at one point participated in plains agriculture, adopted new structures of caste hierarchy while others were pushed further into the forests. The British delineated two major types of Khonds: KutiaKhonds who lived in garjhats or jungle villages, and plains-dwelling Khonds who, according to one ethnologist, had over time acquired a 'tincture of Hinduism' (Hunter 1909: 280). Much of the conflict over settled agrarian spaces during this period, particularly in Kalahandi's lowlands along the present day Rayagada border, can be attributed to the migration of Sambalpuri cultivating classes, known as Kultas, who were able to use lineage networks, land grants and mercantile credit to establish themselves in arable parts of the Central Provinces and southwestern Odisha (Senapati 1980: 35-52).

time of independence, Kalahandi was connected to Raipur in the west and Puri in the east by a single rail line completed in 1883 (Pati 1999a: 348). Beginning in the 1930s, the last Maharaja of Kalahandi attempted to establish an independent province by joining the former territories of the princely Central Provinces; yet in 1948 the district joined the Congress government in Odisha. The estate system, by which the Maharaja had ruled, was left structurally intact many years thereafter, despite legislation and political pressure to dismantle it. As the postcolonial state inherited many of the revenue structures of the British administration, the problem of titling forest land to forest cultivators, who had now presumably been living in these much smaller and estate bounded forests for over a century, was left largely unaddressed. Revenue maps from the early $20^{\text {th }}$ century show Kalahandi's interior forests and hills under singular groupings of Reserve Forest, Village Forest or zamindari. Khond settlements and their agricultural plots were administered for revenue purposes by local collectors who often assessed lands based on approximated seed capacity (Senapati 1980). Long-term ownership was tenuous and rates of outmortgaging, or land sale to non-Khond communities, were high (Deo 2011, Pati 2007b). In the case of forest enclosures, communities were regarded as encroachers of state-owned resources rather than property owners with customary entitlements to forest resources. The often politicized bureaucratic distinctions between Forest Department administered areas and Revenue Department administered areas further complicated attempts at surveying forest land well into the 1960s.

\section{The Legal Basis of Custom}

13 The non-recognition of customary tenures under revenue settlement in Kalahandi are further illustrated by colonial precedents of forest reservation. This is not to say that the category of customary occupancy was absent from the political economic thought of colonial administrators, but that the priority given to reserving forest land as public domain dominated early forest policy making. In his brief history of the 1878 Indian Forest Rights Act, Ramachandra Guha outlines the legal-theoretical bases for distinguishing forms of forest property within the emergent discipline of 'scientific' forestry. One of the chief aims of this discipline was the rational management of forest 
ecosystems through a prioritization of the marketable value of forest biomass (Guha 1990, Rangaranjan 1996). Usufruct land rights within forested areas, championed as they were by the Revenue Department, were fought against by Forest Department interests concerned with the scientific management of specific tree species and the revenue needs articulated in the legal architecture for department sponsored resource extraction..$^{12}$ In princely states like Kalahandi, these resources were further opened to the discretion of ruling families and decisions taken by the Court of Wards. Legal regard for forest dwelling communities was further influenced by powerful local branches of the Imperial Forest Service, the precursor of the Indian Forest Service, whose capacity to protect the forest was, according to some critiques, undermined by foresters' own participation in illicit logging. ${ }^{13}$

Contrary to state directed natural resource management, the category of customary entitlements presents a distinct set of arguments concerning past labor or sustained occupancy as conditions for entitlements that states should not justly expropriate..$^{14}$ In his study of colonial Bengal for instance, Andrew Sartori has shown how the Bengal government developed administrative procedures for recognizing customary land entitlements based on the principle of initial clearing (Sartori 2011). Sartori's case looks at the Sunderbans and the extension of wetland cultivation brought about by state sponsored land tenure for cultivators willing to settle on the arable 'frontier.' This legal articulation of custom was premised on a Lockean relationship between property ownership and labored improvements to land. Custom did not relate to group notions of territorial identity or homeland, but to a productivist relation between property ownership and labor that was seen to benefit both the government and the cultivator. The legal recognition of custom, as envisioned by the Bengal government in Sartori's case, demonstrates the relationship between a productivisit logic of property and forms of liberal governance as a means of meeting developmental ends.

For the purposes of this study, institutional theory regarding proprietary holdings represents perhaps the most influential reformulation of liberal property rights for indigenous claims to custom..$^{15}$ Institutional approaches that emphasize local knowledge and decentralized property ownership have argued that local people are, within specific contexts of property security, potentially more responsible resource managers than government administrators. These approaches have also shown how extra-local disciplining systems, such as the market-based cooperative sale of forest biomass, as earlier attempted under the Joint Forest Management Program (JFM), fail to to adequately conserve forest resources because they do not necessarily strengthen community decision making capacities. Property centered interventions, however, are said to put the power back into the hands of the community, requiring users to deal directly with conservation and allocation issues through collective problem solving. Although under programs like JFM the market is seen as a way to rationalize local resource use, under campaigns for property security the market is localized in the sense that user groups with a direct stake in the 'sustainability' of a given resource are viewed as more likely to respond to resource pressures by making positive adjustments to extraction. Decentralization, in this sense, is an argument for community resources, like forests, to be transferred to the control of community institutions, though with ownership often conceived of at the level of the household or the individual. Property is here both a title to livelihood security and a guarantee of sound resource management (Agrawal \& Ostrom 2001b). ${ }^{16}$ In much of the literature from the institutional economists 
writing on agrarian communities, these dual ends are legitimated through appeals to decentralization's efficacy in improving sustainable resource use (conceptualized in terms of partial conservation and multi-generational utility) and economic solvency, meaning access to the material means of livelihood reproduction.

This theoretical position lends support to instrumentalist notions of indigenous community based institutions, articulating a particular developmentalist vision of labor organization, 'scientific' cultivation methods, and liberal property relations. Because these ideal-typical models of a community based institution cannot be said to be historically located in any particular context, the institutional theory described here suggests that local institutions need to be provided with the 'scientific' tools in order to respond positively to the aforementioned resource pressures (even if, for indigenous communities, it is claimed that these 'scientific' tools did exist at some point though they are now unable to properly function for a variety of reasons). The perceived 'productive' role of community based institutions is therefore conceived before the institutions themselves can be said to exist. This conception of a community based institution articulates a relationship between agriculturalists and natural resources which subsumes other determining relationships, such as local markets for firewood or rises in wages for day construction work, that may significantly impact so-called collective priorities of maintaining or stabilizing a resource pool. The entitlements argued for by proponents of the FRA frequently invoke this dual productivist logic of the imagined community institution: improvements to the natural resource pool as a condition of developmental improvement.

17 As a corrective of land based historical injustices committed against forest dwelling groups, the FRA reflects institutional theory backwards to suggest that unrecognized community resource use in the past legitimates official translations of customary rights in the present. Indigenous communities are depicted as legitimate bearers of these rights because of a presupposed commitment to subsistence forms of responsible ecological stewardship, reflecting, though in an apparently positive light, one of the many $19^{\text {th }}$ century colonial ethnological tropes depicting adivasis as inherent conservationists. ${ }^{17}$ District officials and non-governmental organizations charged with verifying FRA claims are thereby engaged in a type of forensic cartography to re-map indigenous spaces: reclaiming invisible borders by examining dusty voter registration records and ration cards, collecting oral histories, searching for water catchments buried in the forest. These items are the relevant signifiers for legal projections of territorial identification which FRA claimants can use to demonstrate their sustained occupancy on a given tract of forest land. In searching for and ultimately presenting such territorial markers, adivasi communities and their advocates project a stable form of agricultural reproduction centered on land ownership and suggestive of a uniform sharing of a given resource pool.

\section{Identifying Differences in the Forest Economy: Case Studies}

18 The spatial distribution of agricultural settlement in Lanjigarh's forests demonstrates the diversity of socio-economic relationships that determine the context in which land based politics occur. The community institutional approach I have described above pays little attention to the social contexts within which claims to custom are made by primarily focusing on the relationship between insecure property holders and the forest. Here, I 
attempt to explain how these dynamics function in relation to social and spatial attributes of Kalahandi.

Spread throughout the Lanjigarh block in upland settlements, Khond villages typically range from twenty to forty households, though two villages in the block have over one hundred households within their official village boundaries. Villages with larger populations are typically closer to the road, while smaller hamlets demonstrate more socioeconomic homogeneity and are often located in higher elevations or areas with more intensive forest cover. Larger villages are demographically heterogeneous, using small footpaths or tributary streams to internally demark the living arrangements of Khond adivasis and the Scheduled Caste (SC) or Other Backward Caste (OBC) communities that share these spaces.

Rindho Majhi, a member of the Scheduled Caste community upland Sindhibata, described to me his fears concerning new FRA land deeds that were given to individual adivasi households in the village. As I was working in Sindhibata with an NGO on registering FRA applications, Rindho expressed a sense of alienation towards our project. He explained that although his family does not cultivate in the forest, they do gather timber and forest produce that can be sold at monthly markets. He feared that the new property regime would exclude him from this vital economic activity.

21 Rindho is a sharecropper, spending most of his year re-bunding, tilling and harvesting a neighbor's paddy land. The neighbor owns eight acres of paddy in the village, a substantial amount, and is an influential member of Rindho's own community, the sunddhis. Lanjigarhi sunddhis are often scorned by indigenous activists for trading country liquor, a source of widespread debt amongst Khonds. NGO workers in Lanjigarh frequently describe members of the sunddhi community as outsiders. Yet Khonds and sunddhis move within each other's social practices when sharing harvest festivals in the same ritually demarcated spaces and by participating in the joint marketing of goods like sal leaf plates. Although the uneven distribution of resources between Khonds and sunddhis predates the introduction of the FRA in Sindhibata, an interpretation of the Act that would restrict patta claims to Khond households threatened to institutionalize this inequity in novel ways. According to how the District Forest Department had interpreted the Act in other villages, technically landless groups like the sunddhis were expected to be denied proprietary claims. Under the new mandate, sunndhis would potentially be restricted from cultivating on forest plots or accessing the newly mapped village forest without obtaining consent from the Khond community. What would this consent entail? By identifying an equivalence between indigeneity and custom, FRA implementation was thought to effectively remake social access to natural resources according to a communitarian logic. Whether or not this would actually hold for Sindhibata, Rindho's case demonstrates how the political utility of the Act was understood by those individuals who were shut out from its benefits. Further, it allows us to see how plans to decentralize resource governance are foundationally contingent upon the processes that facilitate decentralization. Howsoever democratic community controls over resources may appear to be, it is clear that the state is defining resource distribution selectively. Within a context of unequal beneficiaries with variable facilities for contesting the role of FRA implementers, the facilitator or the implementing agency ultimately holds the tools for how that power is distributed.

In Lanjigarh's villages, government officials and non-governmental organizations count three, and sometimes four, land types based on gradation. These roughly correspond to 
low, medium and high lands. Low lands are paddy growing lands. These areas are stacked against waterways, or are terraced or bunded with mud and sand which typically hold out water for approximately two harvest cycles. ${ }^{18}$ Medium land is land that is naturally irrigated by run-off from the hills and where grains like mandia or ragi are often grown. High lands are also called dongar lands and sometimes podu lands. Dongar lands are areas on Lanjigarh'shills where the forest has been cut or burned away and in its place Khonds now grow staple crops likes mandia or ragi. Dongar lands are where shifting cultivation occurs. Here, in plots of one to three acres typically, Khond households cultivate for approximately three years before moving to another area of the forest contained within the recognized limits of the village's customary boundary. In the new location, the forest growth is burned away so that the ash from sal and other non fruit-bearing trees fertilize the soil. In the old plot, the forest is expected to regenerate. Depending on distribution between forest space and a cultivating population, this cycle can conceivably consist of up to four plots per family, though in Lanjigarh, most families have only one or two. For Khonds, dongar cultivation is a complex investment. Natural predators and pests require cultivating families to build make-shift shelters high up in the hills to watch their ripening crops as harvest cycles approach. They must also compete with neighboring villages, official foresters and illegal timber contractors that have competing visions of how dongar land ought to be valued and used.

Khonds are mostly subsistence agriculturalists, though agricultural wage labor also occupies significant labor time during planting and harvesting cycles for many households. ${ }^{19}$ In my study of twenty-five villages in Lanjigarh, I found that $80 \%$ of surveyed households felt confident that they could secure enough food production, either through harvesting their own crops or through agricultural wage labor, to feed their families for at least six months of the year. Of the $80 \%$, approximately $60 \%$ are landholding, cultivating one to two acres of mostly non-irrigated land. The remaining months of necessary wages are made-up through non-agricultural wage labor, migratory labor, small commercial activity in regional markets, government rations or food subsidies and credit. ${ }^{20}$ Families also depend on larger landholders within the village for grain loans and gifts. In villages at lower elevations, and thus geographically closer to upper caste villages and semi-urban commercial centers, there are greater opportunities for year-round sharecropping, as better irrigated paddy fields owned by upper caste families permit multiple harvests in a single year. Khonds are also more closely linked to labor contractors in the low-land and generally more aware of block infrastructural development projects from which they or another family member might derive a wage. While land ownership is lower here than in more remote, upland villages, there is more arable land overall and thus more dependable sources of income. For Khond villages where arable land is much scarcer, regional migration is routinized. Young Khond men travel west to Raipur, farther west to Delhi and south to Kerala, where contractors have promised construction work, decent wages, housing and phone cards. Men travel these longer distances while women find coolie work at home building bridges across flooded roadways and digging intake wells for internationally funded water projects.

These dynamics are captured in a short story of the forest narrated to me during a harvest festival in Talbora, Lanjigarh's largest village. An older member of the village explained that two Forest Department officials had come to the village during the recent wedding of his son. They had demanded money from him for his family's illegal cultivation in the forest. According to the officials, the money would be used to 
regenerate the bamboo coppices that Talbora Khonds had cut down, and also to protect his family from potential eviction from their dongar lands. The man said he refused to pay and that he scolded the officials for not understanding the futility of conservation in Talbora. The population had grown twice in his lifetime, with Talbora absorbing two neighboring villages during a failed land terracing project sponsored by a Swiss NGO in the 1980s. He said the soil for dongar cultivation had become weak due to shortened fallow periods and that, during heavy rains, crops and sediment washed down from the hills and into the village. Now, his son earned more from sharecropping near the district capital than from cultivating his own one acre plot of dongar.

When speaking of the new FRA land titles approved by the Block Office, the older man explained that neither he nor the government officials even knew where the newly titled plots were, as no one from the government had ever come to map the village forest with the FRA applicants. This was a widespread problem throughout Lanjigarh. Responding to my focus on FRA land, he laughed and said he would just as soon sell his land back to the government or to a private mining company if he could, as he had heard Khonds living closer to Rayagada had done in 2004. ${ }^{21}$ After all, if his son could make more money in wages as a farmhand outside Talbora, his proprietary right in forest land proved less important than other opportunities for wage work.

As we can see from this brief example, forests, while existing as a generalized site of laboring activity, are valued in relation to other income generating opportunities available to specific actors. Maintenance of common resources is, I would argue, as dependent on preexisting social institutions and government oversight as the market forces which shape how and when a common resource is used. For example, in a lower lying village like Punjam, where year round wage labor is available on upper-caste paddy land, forests figure prominently in discourses of adivasi identity but not in terms of their centrality to household income. In more interior, heterogeneous villages where SC and $\mathrm{OBC}$ communities want greater access to forests for foraging or even cultivating activities, forests serve as both a discourse of identity and as a central site of livelihood reproduction for Khond communities.

In a similar sense, resource pressures within village watersheds can be seen to undergird differential conceptions of what it means to qualify as a member of a Khond community and also, in regard to developmental schemes that are enumeration based like the FRA, the relative importance of legal recognition. For instance, on the far western side of Sindhibata there is a small hamlet of five Khond households cornered between two reserve forests. The five households are made up of five brothers and their families. They live next to what appears to be the most heavily cultivated part of Sindhibata's watershed and are divided from the larger villages of Sahajpada to the east and Sindhibhata to the south by a small river and dense jungle. Although they are secluded and their village is often overlooked by the local NGO working in the area, the brothers explain that they prefer it that way.

In a meeting with the NGO facilitating FRA claims in the watershed, the brothers told me that they try not to practice shifting cultivation because it brings trouble from the Forest Department and that they harvest enough from cultivating paddy and ragi in low and medium land by the river. One brother raises goats and sets them out to graze on land near the Sahajpada border. Sometimes, he said, people from Sahajpada bring bullocks onto his grazing land that break apart the soil and eat up all the small grasses. 
When I asked if they were going to apply for the FRA when the forest activists came back to the village the following season, the eldest brother told me that they would only apply if they had to. I asked him what he meant by this and why it was not important to him to seek out the activists for recognition of his land. He explained that they would only apply if people in Sindhibata applied for forest land that did not belong to them. He said that once villagers in Sindhibata get forest land they destroy the forest for dongar and that his family depended on the forest for tubers, fruits and other plants. Because the forest had been denuded in the areas directly surrounding Sindhibata, he told me, the Sindhibata villagers now came to his section of the forest to look for the mahua flower to prepare the alcohol that is central to Khond ritual life. If forest land was given to Sindhibata for agricultural plots, no one would have any control over which forests were left 'wild' and which were burned for dongar. Even their ability to ferment mahua would suffer. As a result he advised his brothers that they should apply for the FRA only to make counterclaims against Sindhibata's Khonds. The law would then serve the purpose of demarcating territory between the Khonds; denying one community's livelihood claims to promote another community's vision of forest conservation.

\section{Conclusion}

The brief case studies I have submitted for this essay have been intended to convey a sense of the diversified forms of livelihood reproduction and resource use in the Lanjigarh block. I have used this notion of diversification, or heterogeneity, to think about 'custom' as a political economic category with a distinctive local trajectory in the lives of cultivators for whom the FRA offers potential benefits. These case studies, of course, omit much in regard to popular politics in Lanjigarh, though I have proceeded in this way in order to focus specifically on disjunctures between how the FRA envisions customary practices of Khond groups and the present state of livelihood practices that I have witnessed through my research.

While more work will be needed to develop a comprehensive picture of how Lanjigarh's agrarian economy fits within a wider world of migratory labor practices and informal wage labor, this essay has begun to consider how the diversification of livelihoods in Lanjigarh destabilize notions of a static 'custom.' Available scholarship on the FRA, by focusing primarily on the relationship between pre-defined 'forest dwelling communities' and the state, often uncritically reproduces the economic and social categories presented in the law. While this is frequently a strategic concern, that is to highlight the economic vulnerability of these communities and to pose a critique to expropriatory state-led industrial development, there are significant problems with the representation of this relationship as a primordial struggle concerning indigenous communities, their land and the state. At an analytical level, this depiction of the relationship between the state and adivasis presents a historical narrative that takes a rather simplified view of land use and resource pressures. Culturalist tropes of indigenous communities have, as Alpa Shah has shown elsewhere, presented indigenous groups as collectivities outside of historical and economic change, when abundant evidence in fact points to the highly complex participation of indigenous groups in both markets and state politics Shah (2012).

By embedding the practice of custom in the social contexts in which this ideology gains salience, the implementation of the FRA can be understood as it is integrated into local struggles over resources. In Lanjigarh, these struggles highlight longer histories of 
mapping and codifying indigenous space which, as the weak progress of the FRA partially signifies, remains a highly contested space of both mobile and fixed agrarian communities vying for different forms of livelihood and state sanctioned entitlements. In this context, one can observe a legally mediated relationship developing between land, history and identity, thereby tying access to resources to the accessibility of historical artifacts that legitimate Khonds as forest agriculturalists. Here, custom frames an argument, admittedly often strategic, for looking at forest agroecological spaces in a particularly homogenizing way. Yet rather than demonstrating a coherent sense of communal needs in Lanjigarh, the flagging legal codification of these unstable land tenures under the FRA reveals in part the diversification of livelihood opportunities and ecological constraints,and poses further analytical questions of how to represent the communities actively engaged in the land politics of India's Scheduled Areas.

\section{BIBLIOGRAPHY}

Agrawal, Arun; Ostrom, Elinor (2001) 'Collective Action, Property Rights, and Decentralization in Resource Use in India and Nepal', Politics and Society, 29(4), pp. 485-514.

Agrawal, Arun; Sivaramarishnan, Kalyanakrishnan (eds.) (2000) Agrarian Environments: Resources, Representations and Rule in India, Durham: Duke University Press.

Ahuja, Ravi (2009) Pathways of Empire: Circulation, Public Works, and Social Space in Colonial Orissa, 1780-1914, New Delhi: Orient Black Swan.

Banerjee, A.; Behera, S.; Bose, I.; Dasgupta, P.; Ghosh, S; Misra, P. S.; Rao, P.T.; Reddy, M.G.; Sarap, K.; Sarin, M.; Springate-Baginski, 0. (2009) 'Redressing Historical Injustice Through the Indian Forest Rights Act 2006', Institutions for Pro-Poor Growth Discussion Papers, URL: http:// www.ippg.org.uk/papers/dp27.pdf (Accessed 20 August 2012)

Banerjee, Prathama (2006) Politics of Time: 'Primitives' and History Writing in a Colonial Society, Oxford: Oxford University Press.

Chatterjee, Partha (2006) Politics of the Governed: Reflections on Popular Politics in Most of the World, New York: Columbia University Press.

Chakrabarty, Dipesh (2009) 'The Climate of History: Four Theses', Critical Inquiry, 35(2), pp. 197222.

Dash, Mamata; Sahu, Subrat K. (2011) 'Expropriation of Land and Cultures: The Odisha Story and Beyond', Social Change, 41(251), pp. 252-271.

Deo, Fanindam (2011) 'Land Distribution Programs in Odisha-A Social Audit in Nuapada', Social Change, 41(271), pp. 272-293.

Engerman, Stanley L.; Metzger, Jacob (eds.) (2004) Land Rights, Ethno-Nationality, and Sovereignty in History, New York: Routledge.

Fraser, Nancy; Honneth, Axel (2003) Redistribution or Recognition: A Political Philosophical Exchange, London: Verso. 
Ghose, Kaushik (1999) 'A Market for Aboriginality: Primitivism and Race Classification in the Indentured Labour Market of Colonial India', in Gautam Bhadra, Gyan Prakash, Susie Tharu (eds.), Subaltern Studies X: Writings on South Asian History and Society, Delhi: Oxford University Press.

Guha, Ramachandra (1990) 'An Early Environmental Debate: The Making of the 1878 Forest Act', Indian Economic Social History Review, 27(65), pp. 65-84.

Hale, Charles (2002) 'Does Multiculturalism Menace? Governance, Cultural Rights, and the Politics of Identity in Guatemala', Journal of Latin American Studies, 34(3), pp. 485-524.

Hardiman, David (1987) The Coming of the Devi: Adivasi Resistance in Western India, New Delhi: Oxford University Press.

Harris-White, Barbara; Shah, Alpa (2011) 'Resurrecting Scholarship on Agrarian Transformations', Economic and Political Weekly, 39(46), pp. 13-8.

Herring, Ronald (1983) Land to the Tiller: The Political Economy of Land Reform in South Asia, New Haven: Yale University Press.

Hunter, William Wilson (1909) Imperial Gazeteer of India Volume 15, Oxford: Clarendon.

Iqbal, Iftekhar (2010) The Bengal Delta: Ecology, State, and Social Change, 1840-1943, Basingstoke: Palgrave Macmillan.

NABCONS Orissa Regional Office (2007) 'Report of the Concurrent Evaluation Study of RLTAP in KBK Districts’, Bhubaneswar: Civic Center, URL: http://www.odisha.gov.in/p\&c/Download/ Economic_plantation.pdf (Accessed 2 October 2011)

Karlsson, Bengt (2003) 'Anthropology and the 'Indigenous Slot': Claims to and Debates about Indigenous Peoples' Status in India', Critique of Anthropology, 23(4), pp. 403-23.

Kerr, John M.; Kumar, Kundan (2012) ‘Democratic Assertions: The Making of India's Recognition of Forest Rights Act', Development and Change, 43(3), pp. 751-71.

Letter to the Editor (1903) 'Far from the Beaten Track', Times of India, 26 February.

Madheswaran, S.; Rajasekhar, D; Sahu, Gagan Bihari (2009) 'Credit Constraints and Distress Sales in Rural India: Evidence from Kalahandi District, Orissa', The Journal of Peasant Studies, 31(2), pp. 210-241.

Mitchell, Timothy (2005) 'The Work of Economics: How a Discipline Makes its World', European Journal of Sociology, 46(2), pp. 297-320.

Nanda, Chandi Prasad (2009) Vocalizing Silence: Political Protests in Orissa, 1930-1942, New Delhi: Sage. Ostrom, Elinor (2000) 'Collective Action and the Evolution of Social Norms', The Journal of Economic Perspectives, 14(3), pp. 137-158.

Pati, Biswamoy (1999) 'Environment and Social History: Kalahandi, 1800-1950', Environment and History, 5(3), pp. 347-359.

Pati, Biswamoy (2007) 'The Order of Legitimacy: Princely Odisha, 1850-1947' in Waltraud Ernst, Biswamoy Pati (eds.) India's Princely States: People, Princes and Colonialism, Oxford: Oxford University Press, pp. 85-98.

Prabhu, Pradip (2010) 'Inclusion in Law and Exclusion in Praxis: The Scheduled Tribes and Other Traditional Forest Dwellers (Recognition of Forest Rights) Act, 2006', Socio-Legal Review 6, pp. 121-140.

Rangaranjan, Mahesh (1996) Fencing the Forest: Conservation and Ecological Change in India's Central Provinces 1860-1914, Delhi: Oxford University Press. 
Sarangi, T.K.; Sarap, K. (2010) Forest Governance in Orissa: Working of Participatory Institutions and Impact on Livelihood, Sambalpur University Position Paper, URL: http://www.ecoinsee.org/6bconf/ Theme\%20G/G.2.3\%20Kailas.pdf (Accessed 20 August 2012)

Sartori, Andrew (2011) 'A Liberal Discourse of Custom in Colonial Bengal', Past and Present 212(1), pp. 163-97.

Senapati, Nilamani. (1980) Orissa District Gazetteers: Kalahandi, Cuttack: Department of Revenue.

Shah, Alpa (2012) 'Against Eco-incarceration: Class Struggle and Indigenous Rights in India', Economic and Political Weekly, 48(21), pp. 32-24.

Sivaramakrishnan, Kalyanakrishnan (1999) Modern Forests: Statemaking and Environmental Change in Colonial Eastern India, Delhi: Oxford University Press.

Sivaramakrishnan, Kalyanakrishnan (2012) 'Transition Zones: Changing Landscapes and Local Authority in Southwest Bengal, 1880s-1920s', in Mahesh Rangaranjan, Kalyanakrishnan Sivaramakrishnan (eds.) India's Environmental History, New Delhi: Permanent Black.

Smith, Neil (2008) Uneven Development: Nature, Capital, and the Production of Space, Athens: The University of Georgia Press.

Skaria, Ajay (1999) Hybrid Histories: Forests, Frontiers and Wildness in Western India, Delhi: Oxford University Press.

Skinner, Quentin (1991) 'The Idea of Negative Liberty', in Richard Rorty, Jerome B. Schneewind \& Quentin Skinner (eds.), Philosophy in History: Essays in the Historiography of Philosophy, Cambridge: Cambridge University Press, pp. 193-222.

The Times of India. 1985. 'Starvation Deaths in Kalahandi Denied', 31 July.

\section{NOTES}

1. For the purposes of this study, all FRA claims analyzed here concern individual rather than community claims. Although the FRA calls for the recognition of both types of claims, in Lanjigarh, as in most other Scheduled Areas of India where the Act has been implemented, local government has largely only been willing to settle with individual claimants.

2. India. Preamble of the Scheduled Tribes and Other Traditional Forest Dwellers (Recognition of Forest Rights) Act. 2007.

3. Agrawal \& Sivaramakrishnan (2000), particularly the introduction and the article by Vinay Gidwani.

4. See Herring (1983) and Iqbal (2010), particularly Chapter 8.

5. My use of the word 'indigenous' in this essay does not proceed unaware of its problematic applications. I do think, however, that the term 'indigenous' does reflect the global discursive categories of indigeneity used by advocacy organizations to promote a particular historical vision of indigenous rights, which I see reflected in the FRA. In practice, that is in the regional politics of Kalahandi in which Khond adivasis are engaged, the terms indigenous and adivasi both intersect and diverge from one another, depending on the types of political articulations and developmental claims individuals and groups strive to make. These words and their identitarian implications articulate with particular logics and goals and therefore should not be simplistically conflated with one another. If I have collapsed these terms into one another for the purposes of this introduction, it is not that I am unaware of these dynamics, but that I am attempting to think about the FRA as a document that mobilizes discourses of 'indigeneity' in local, national and global contexts. 
6. Conspicuously absent from this paper is any attention paid to thinking through problems of social differentiation and resource access in relation to gender. Because the FRA requires both husbands and wives (where applicable) for granting FRA patta, an analysis of women's experiences is fundamental to any critical reading of the FRA. This shortcoming is rendered in an expanded version of this article that is currently under revision.

7. The classic outline of this history can be found in the outline to Hardiman (1987). See also Shah (2012).

8. I do not have the space here to map the history of CSD and its influence within adivasi advocacy circles, however many of the sources I cite here have been written by individuals closely connected to the group. Suffice it to note that although the FRA as passed in 2006 does not reflect the entirety of CSD's concerns over adivasi forest settlement, the group can be credited with steering many of the chief concerns promoted by the FRA. See the important article by CSD convener Pradip Prabhu (2010).

9. It is important to add here that these developments have been actively noted and contested by advocacy groups. During the National Forum for Forest People and Forest Workers national conference in November 2011 these were a few of the chief concerns raised to the Minister of Tribal Affairs. These concerns are also found in Prabhu (2010).

10. Village Forest is a settlement term determining the rights, boundaries and vested control over the resources of the forest. Reserve Forest denotes a similar set of privileges vested with the Forest Department, typically manifesting as large area of conservation land where agriculture and home construction cannot occur. These denominations are frequently contested and difficult to map, particularly in areas with large village settlements. In the Taliguda and Carnomunda watershed, as in many other parts of Lanjigarh, the Forest Department tolerates a certain degree of forest encroachment, though most often for home construction rather than dongar. It is important to note that the actual village boundaries of both Taliguda and Carnomunda are recognized as encroachments on Reserve Forest. Therefore, FRA pattas for these villages would include homestead pattas in addition to agricultural plot pattas, thereby giving the villages legal recognition in the block.

11. See The Times of India News Service 1985.

12. The story of Indian railway sleepers is perhaps the best known. For an important review of these tensions in eastern India, please see Sivaramakrishnan (2012).

13. For an example see Dash \& Sahu (2011).

14. For a sustained study of this subject see Engerman \& Metzger (2004).

15. Without over simplifying the significant interventions of these two authors, I am specifically thinking of Elinor Ostrom (2000a), and Arun Agrawal's and Ostrom's (2001b) co-authored work on new institutional theory. The co-authored paper effectively details the pitfalls of decentralization from an administrative perspective, making the case (one which I think applies for FRA implementation) that complex and multi-interested bureaucratic systems often prevent decentralization from occurring by working against the social institutions which will replace external administration. My critique here of decentralization as outlined by the FRA questions the modularity of social institutions across diverse ecological and social fields, and also the centrality of property in theorizing subsistence agriculture in Kalahandi. Mitchell (2005) for instance presents a case-study of the neoliberal presuppositions that underlie new institutional theory, particularly in the work of Douglas North. As found in Mitchell, my research also suggests that prior economic relationships are unduly bracketed out of studies concerned with the functioning of community based institutions when surveying for the suitability of FRA implementation.

16. Skinner (1991) offers an historical analysis of this point.

17. For discourses of indigeneity in the Indian context see Bannerjee (2006), Skaria (1999), and Ghose (1999). 
18. There is variation through Lanjigarh regarding when land is re-bunded and the materials used to do so. Higher elevation areas typically correspond to less fortified bunding structures, though there are exceptions. The time period of 'two harvest cycles' is calculated from field interviews.

19. Madheswaran et al. (2009) present an econometric analysis of this trend focusing on monopsonic grain markets and credit rationing. Hariss-White and Shah (2011) have presented an historic overview of these transitions at the national level.

20. For a block level comparison, Madheswaran et al. (2009: 225-229).

21. His reference here is the Niyamgiri mining project by Vedanta.

\section{ABSTRACTS}

The Indian Recognition of Forest Right's Act defines a category of land tenure that is premised upon the recognition of customary entitlements to forest resources entitled to forest dwelling groups. In this paper I examine how the concept of custom is defined by livelihood practices and proprietary rights. I argue that 'custom' presents an understanding of agrarian practices that is both a claim to political rights and a normative description of livelihood practices. I analyze the implementation of the Forest Rights Act in the Lanjigarh block of Kalahandi, Odisha, in order to understand what this concept of custom signifies within the political economic setting it is meant to describe.

INDEX

Keywords: Forest Rights, Kalahandi, Kondhs, Community Forestry, Custom, Odisha

\section{AUTHOR}

MATTHEW B. SHUTZER

PhD Candidate, New York University, Department of History 